\title{
Degree-day model for predicting emergence of spruce spider mite (Oligonychus ununguis Jacobi) from overwintering eggs
}

\section{Suma temperatur efektywnych w prognozowaniu pojawu pierwszego pokolenia przędziorka sosnowca (Oligonychus ununguis Jacobi)}

\author{
Ewa Puchalska*, Barbara Czajkowska
}

\begin{abstract}
Summary
Spruce spider mite is a key pest of ornamental coniferous plants growing in Polish nurseries. Predicting the time of eclosion of the pest overwintering eggs may be used for the proper timing of spray application against its larvae. Termination of diapause of Oligonychus ununguis winter eggs diapause was observed at the beginning of January. The threshold temperature for postdiapause development was determined as $5^{\circ} \mathrm{C}$. Degree-days accumulation from 1 January to $50 \%$ eclosion for overwintering eggs of spruce spider mite yielded a mean of $119^{\circ} \mathrm{D}, 100 \%$ of eclosion was observed at $183^{\circ} \mathrm{D}$.
\end{abstract}

Key words: degree-days; threshold temperature; phenology model

\section{Streszczenie}

Przędziorek sosnowiec jest kluczowym szkodnikiem drzew i krzewów iglastych uprawianych w szkółkach roślin ozdobnych. Właściwe prognozowanie pojawu larw pierwszego pokolenia tego roztocza umożliwia precyzyjne wykonanie zabiegu jego zwalczania i ogranicza ilość zabiegów chemicznymi środkami ochrony roślin w czasie sezonu wegetacyjnego. W badaniach przeprowadzonych w niniejszej pracy ustalono, że w Polsce centralnej szkodnik kończy diapauzę zimową na początku stycznia. Jako najbardziej prawdopodobną wartość temperatury zera fizjologicznego dla rozwoju jaj zimujących przędziorka sosnowca przyjęto $5^{\circ} \mathrm{C}$. Suma temperatur efektywnych potrzebna do wylęgu 50\% larw szkodnika z jaj zimujących wyniosła 119 stopnio-dni, zaś do wylęgu 100\% larw 183 stopnio-dni.

Słowa kluczowe: stopnio-dni; zero fizjologiczne; model fenologiczny

\footnotetext{
Szkoła Główna Gospodarstwa Wiejskiego w Warszawie Wydział Ogrodnictwa, Biotechnologii i Architektury Krajobrazu

Samodzielny Zakład Entomologii Stosowanej

Nowoursynowska 159, 02-776 Warszawa

*corresponding author: ewa_puchalska@sggw.pl
} 


\section{Wstęp / Introduction}

Przędziorek sosnowiec (Oligonychus ununguis Jacobi), to szkodnik drzew i krzewów iglastych, szczególnie groźny i problematyczny w zwalczaniu w szkółkach roślin ozdobnych (Puchalska 2014). Jego żerowanie prowadzi do drastycznych zaburzeń metabolizmu komórkowego (Kiełkiewicz i wsp. 2005; Puchalska 2006), co objawia się szybką utratą walorów dekoracyjnych rośliny i znacznym spadkiem jej zdrowotności (Bogatko i wsp. 1987). Niewielkie wymiary ciała tego roztocza utrudniają jego wczesne wykrycie jeszcze przed pojawieniem się wyraźnych objawów jego żerowania. Tymczasem wysokie wartości parametrów reprodukcyjnych szkodnika sprawiają, że nieumiejętnie zwalczany może w krótkim czasie rozwijać bardzo liczne populacje (Czajkowska i wsp. 2003). W ochronie roślin iglastych przed przędziorkiem sosnowcem ważne jest ustalenie terminu pojawu pierwszego pokolenia szkodnika. Wykonane wówczas opryskiwanie pozwala ograniczyć szkodliwość omawianego gatunku oraz przyczynia się do redukcji liczby zabiegów przeprowadzanych w sezonie wegetacyjnym, a zatem do ograniczenia kosztów produkcji i ryzyka środowiskowego związanego ze stosowaniem chemicznych środków ochrony roślin.

Skuteczną metodą wyznaczania optymalnego terminu zwalczania szkodników jest określenie sumy temperatur efektywnych (STE) potrzebnej do osiągnięcia przez nie konkretnego stadium rozwojowego (Ahmad i wsp. 1995; Herms 2004; Murray 2008; Jakubowska i Walczak 2010). W przypadku przędziorka sosnowca prace $\mathrm{z}$ tego zakresu prowadzono w Finlandii, Japonii i Stanach Zjednoczonych (Löyttyniemi 1970; Akita 1971; Richmond i Shetlar 1996). Niemniej wyniki tych badań nie są zbieżne i wskazują na konieczność wyznaczania STE dla konkretnego regionu występowania szkodnika.

Celem pracy było określenie sumy ciepła niezbędnej do wylęgu larw pierwszego pokolenia przędziorka sosnowca oraz ustalenie, która $\mathrm{z}$ podawanych $\mathrm{w}$ literaturze wartości temperatury zera fizjologicznego rozwoju jaj zimujących szkodnika może być uznana za najbardziej prawdopodobną w warunkach Polski centralnej.

\section{Materiały i metody / Materials and methods}

W warunkach laboratoryjnych przez kolejne dwa lata prowadzono badania nad terminem zakończenia diapauzy jaj przędziorka sosnowca. W tym celu od listopada do kwietnia, co miesiąc, pobierano po 30 pędów świerka pospolitego z jajami zimowymi szkodnika. Każdorazowo, po określeniu liczby jaj (minimum 30 jaj stanowiło powtórzenie, stosowano minimum 10 powtórzeń), pędy umieszczano w komorze hodowlanej (Versatile Environmental Test Chamber MLR-350H, Japonia) w temperaturze $20^{\circ} \mathrm{C}$, wilgotności względnej powietrza 60-70\% i przy zmiennym fotoperiodzie korespondującym z warunkami naturalnymi. Co drugi dzień przy użyciu mikroskopu stereoskopowego liczono i usuwano wylęgające się larwy. Obserwacje zakończono w momencie wylęgu larw ze wszystkich żywych jaj szkodnika. Długość rozwoju post- diapautycznego wyrażono liczbą dni, jaka upłynęła od umieszczenia jaj w komorze hodowlanej do wylęgu 50 i 100\% larw Oligonychus ununguis. Otrzymane wyniki porównano testem Kruskala-Wallisa, a grupy homogeniczne wydzielono stosując Student-Newman-Keuls test przy poziomie istotności $\mathrm{p}=0,05$.

Sumę temperatur efektywnych, potrzebną do wylęgu larw przędziorka sosnowca $\mathrm{z}$ jaj zimujących wyliczono $\mathrm{w}$ oparciu o dane pochodzące $\mathrm{z}$ trzyletnich obserwacji polowych. Badania prowadzono na terenie Parku Ursynowskiego w Warszawie, na około trzydziestoletnich drzewach świerka pospolitego (Picea abies L). Z chwilą pojawienia się na nich pierwszych larw $O$. ununguis, zakładano doświadczenie zachowujące warunki naturalne. Ze świerków pobierano około $15 \mathrm{~cm}$ pędy $\mathrm{z}$ jajami zimowymi badanego roztocza. Po przeliczeniu jaj (minimum 30 jaj stanowiło powtórzenie, stosowano minimum 10 powtórzeń) pędy umieszczano w plastikowych fiolkach $\mathrm{z}$ wodą zamykanych gumową pokrywką z otworem pozwalającym na wsunięcie pędu. Otwór zabezpieczano plasteliną, zaś brzegi przykrywki pokrywano warstwą ekologicznego kleju uniemożliwiającego ucieczkę wylęgającym się roztoczom. Na czas doświadczenia pędy pozostawiano w warunkach naturalnych, pod zadaszeniem, chroniącym je przed bezpośrednim działaniem opadów atmosferycznych. Kontrolę wylęgu prowadzono w ten sam sposób, jak w badaniach laboratoryjnych.

Do oszacowania sumy temperatur efektywnych posłużono się wzorem Yang i wsp. (1995): $f_{\mathrm{i}}(\mathrm{x})=\left(\mathrm{T}_{\mathrm{i}}-\mathrm{x}\right) \times \mathrm{d}_{\mathrm{i}}$, gdzie: $T_{i}-$ oznacza średnią temperaturę dobową, $x-$ wartość temperatury zera fizjologicznego, zaś $\mathrm{d}_{\mathrm{i}}-$ kolejny dzień rozwoju embrionalnego.

W oparciu o dane literaturowe, w pracy przyjęto cztery warianty terminu, od którego sumowano temperatury efektywne (tzw. biofix): (A) od pierwszego stycznia (według Löyttyniemi 1970) - począwszy od pierwszego dnia $\mathrm{z}$ temperaturą powyżej zera fizjologicznego; (B) od pierwszego stycznia - od momentu, gdy przez kolejne trzy dni średnia temperatura dobowa przekraczała wartość zera fizjologicznego; (C) od pierwszego marca (według Richmond i Shetlar 1996) - od pierwszego dnia z temperaturą powyżej zera fizjologicznego; (D) od pierwszego marca - od momentu, gdy przez kolejne trzy dni średnia temperatura dobowa przekraczała wartość zera fizjologicznego.

Dla każdego z czterech powyższych wariantów czasowych (A, B, C, D) założono trzy możliwe wartości temperatury zera fizjologicznego dla jaj zimujących O. ununguis: (A) $5^{\circ} \mathrm{C}$ (według Löyttyniemi 1970); (B) $5,6^{\circ} \mathrm{C}$ (według Richmond i Shetlar 1996) oraz (C) $7,1^{\circ} \mathrm{C}$ (według Akita 1971).

Za każdym razem określano sumę temperatur efektywnych potrzebną do wylęgu 50 i $100 \%$ larw pierwszego pokolenia przędziorka sosnowca. Za najbardziej prawidłowe uznano termin i temperaturę zera fizjologicznego, dla których określona suma temperatur efektywnych charakteryzowała się najmniejszym współczynnikiem zmienności $\left(C V_{\text {day }}\right)$ (według Trottier i Herne 1979). Wykaz średnich temperatur dobowych otrzymano z Zakładu Meteorologii i Klimatologii w Katedrze Inżynierii Wodnej i Rekultywacji Srodowiska Szkoły Głównej Gospodarstwa 
Wiejskiego w Warszawie, mającej swoje punkty pomiarowe $\mathrm{w}$ miejscu prowadzonych badań polowych (Park Ursynowski).

\section{Wyniki i dyskusja / Results and discussion}

Długość rozwoju postdiapautycznego, badana w warunkach laboratoryjnych, zależała istotnie od terminu inkubacji jaj zimujących szkodnika (tab. 1). W przypadku prób przeniesionych do komory klimatycznej w listopadzie uzyskano wylęg jedynie z 48\% badanych jaj. Pierwsze larwy zaczęły wylegać się dopiero po upływie $21 \mathrm{dni}$. Połowa wszystkich larw, które uzyskano z jaj pobranych w listopadzie, wylęgła się po około 29 dniach inkubacji. Pozostałe zaś dopiero po kolejnych 23 dniach (łącznie po 52 dniach inkubacji). Długość rozwoju jaj zebranych w warunkach naturalnych na początku grudnia była istotnie krótsza niż w przypadku jaj zebranych w listopadzie. Po około 30 dniach obserwacji odnotowano wylęg z $88 \%$ jaj zebranych $w$ tym terminie, przy czym połowa larw wylęgła się w ciągu pierwszych 19 dni doświadczenia. $\mathrm{Z}$ jaj przeniesionych do laboratorium w styczniu uzyskano wylęg rzędu 94,6\%. Veerman (1985) dowodzi, że w przypadku gatunków, u których stadium diapauzującym są jaja, w warunkach laboratoryjnych, wylęganie się larw z jaj zimujących z reguły osiąga swoje maksimum w połowie zimy. $Z$ jaj inkubowanych w styczniu połowa larw wylęgła się w ciągu pierwszych dwóch tygodni inkubacji, a pierwsze larwy obserwowano już po 5 dniach w temperaturze $20^{\circ} \mathrm{C}$. W przypadku jaj $O$. ununguis przenoszonych do laboratorium w kolejnych miesiącach (luty, marzec, kwiecień), liczba dni potrzebna do wylęgu $50 \%$ larw malała sukcesywnie i wyniosła odpowiednio 7,$7 ; 5,3$ i 4,3. Podobną zależność obserwowano między terminem inicjacji rozwoju postdiapautycznego a wylęgiem larw ze 100\% jaj badanego szkodnika. $Z$ jaj umieszczonych w warunkach laboratoryjnych w lutym, marcu i kwietniu, jedynie niewielki odsetek (od 4,8 do $0,2 \%$ ) stanowiły te, z których nie uzyskano wylęgu. Dane te wskazują na to, iż brak wylęgu larw wynika w tym przypadku $\mathrm{z}$ naturalnej śmiertelności w czasie rozwoju embrionalnego nie zaś $\mathrm{z}$ pozostawania $\mathrm{w}$ fazie diapauzy (tab. 1). Uzyskane wyniki korespondują z doniesieniami Brammanis (1957) i Löyttyniemi (1970). Można zatem przyjąć, że w warunkach Polski centralnej znaczna część jaj O. ununguis kończy diapauzę na przełomie grudnia i stycznia.

Trafność prognozowania terminu pojawienia się określonego stadium rozwojowego szkodnika na podstawie sumy temperatur efektywnych, zależy także od dokładności oszacowania wartości zera fizjologicznego jego rozwoju (Łabanowski 1979). Dla każdego z przyjętych wariantów czasowych, najniższe wartości współczynnika zmienności $\left(C V_{\text {day }}\right)$ otrzymano sumując średnie temperatury dobowe powyżej $5^{\circ} \mathrm{C}$. W związku z powyższym uznano, że wśród badanych temperatur zera fizjologicznego najbardziej prawdopodobną wartością zera fizjologicznego dla rozwoju embrionalnego przędziorka sosnowca, w warunkach klimatycznych Polski centralnej jest temperatura $5^{\circ} \mathrm{C}$. W dalszej kolejności porównywano sumy temperatur efektywnych (powyżej $5^{\circ} \mathrm{C}$ ) potrzebne do wylęgu 50 i $100 \%$ larw $O$. ununguis z uwzględnieniem poszczególnych kryteriów czasowych. Najmniejszą zmienność uzyskano sumując temperatury efektywne już od pierwszego dnia $\mathrm{W}$ roku $\mathrm{z}$ temperaturą powyżej zera fizjologicznego. Współczynnik zmienności dla sumy ciepła potrzebnej do wylęgu 50 i $100 \%$ larw szkodnika wyniósł wówczas odpowiednio 12,59 i 14,50\% (tab. 2). Przyjmując za zero fizjologiczne $5^{\circ} \mathrm{C}$ i sumując średnie temperatury dobowe od pierwszego dnia w styczniu z temperaturą powyżej wartości progowej ustalono, że do wylęgu 50\% larw przędziorka sosnowca z jaj zimujących

Tabela 1. Czas i wielkość wylęgu larw z jaj zimujących przędziorka sosnowca - Oligonychus ununguis w zależności od terminu ich inkubacji (brak tych samych liter przy średnich w danej kolumnie wskazuje na różnice istotne statystycznie, Student-Newman-Keuls test, przy $\mathrm{p}=0,05$ )

Table 1. Hatching time of spruce spider mite - Oligonychus ununguis winter eggs, depending on the time of incubation (means within a column followed by different letters are significantly different Student-Newman-Keuls test for $p=0.05$ )

\begin{tabular}{|c|c|c|c|}
\hline $\begin{array}{l}\text { Termin zbioru prób/inkubacji } \\
\text { Sampling/incubation date }\end{array}$ & $\begin{array}{c}\text { Dni do } 50 \% \text { wylęgu } \\
\text { Days to } 50 \% \text { of eclosion } \\
( \pm \mathrm{SE})\end{array}$ & $\begin{array}{c}\text { Dni do } 100 \% \text { wylęgu } \\
\text { Days to } 100 \% \text { of eclosion } \\
( \pm \mathrm{SE})\end{array}$ & $\begin{array}{c}\% \text { jaj, z których uzyskano wylęg } \\
\% \text { of cumulative hatching } \\
( \pm \mathrm{SE})\end{array}$ \\
\hline $\begin{array}{l}4 \text { listopad } \\
\text { November } 4\end{array}$ & $\begin{array}{r}28,7 \\
( \pm 0,88)\end{array}$ & $\begin{array}{r}52,0 \\
( \pm 0,57)\end{array}$ & $48,0( \pm 2,92)$ \\
\hline $\begin{array}{l}4 \text { grudzień } \\
\text { December } 4\end{array}$ & $\begin{array}{r}19,3 \\
( \pm 0,33)\end{array}$ & $\begin{array}{r}29,7 \\
( \pm 0,33)\end{array}$ & $88,0( \pm 2,21)$ \\
\hline $\begin{array}{l}4 \text { styczeń } \\
\text { January } 4\end{array}$ & $\begin{array}{r}14,3 \\
( \pm 1,45)\end{array}$ & $\begin{array}{r}30,7 \\
(+0,33)\end{array}$ & $94,6( \pm 0,41)$ \\
\hline $\begin{array}{c}4 \text { luty } \\
\text { February } 4\end{array}$ & $\begin{array}{r}7,7 \\
( \pm 1,20)\end{array}$ & $\begin{array}{r}15,7 \\
( \pm 0,33)\end{array}$ & $96,9( \pm 0,41)$ \\
\hline $\begin{array}{l}4 \text { marzec } \\
\text { March } 4\end{array}$ & $\left.\begin{array}{r}5,3 \\
( \pm 0,33)\end{array}\right)$ & $\begin{array}{r}12,7 \\
( \pm 0,33)\end{array}$ & $95,2( \pm 1,69)$ \\
\hline $\begin{array}{l}4 \text { kwiecień } \\
\text { April } 4\end{array}$ & $\begin{array}{r}4,3 \\
( \pm 0,33)\end{array}$ & $\begin{array}{r}6,3 \\
( \pm 0,66)\end{array}$ & $99,8( \pm 0,20)$ \\
\hline- & $\mathrm{P}=0,0004$ & $\mathrm{P}=0,0005$ & - \\
\hline
\end{tabular}


Tabela 2. Sumy temperatur efektywnych (stopnio-dni $-{ }^{\circ} \mathrm{D}$ ) potrzebne do wylęgu 50 i $100 \%$ larw z jaj zimujących przędziorka sosnowca, obliczone dla różnych temperatur zera fizjologicznego oraz dla czterech wariantów biofix (w kolumnach podano średnie z 3 lat badań, wielkość błędu standardowego \pm SE oraz wartość współczynnika zmienności)

Table 2. Cumulative degree-days $\left({ }^{\circ} \mathrm{D}\right)$ to 50 and $100 \%$ hatching of spruce spider mite winter eggs, estimated for different threshold temperatures and biofix (means from three-years observations, standard errors and variance coefficients)

\begin{tabular}{|c|c|c|c|c|c|c|c|}
\hline & \multirow{4}{*}{ Biofix } & \multicolumn{6}{|c|}{ Temperatura progowa - Threshold temperature } \\
\hline & & \multicolumn{2}{|c|}{$5,0^{\circ} \mathrm{C}$} & \multicolumn{2}{|c|}{$5,6^{\circ} \mathrm{C}$} & \multicolumn{2}{|c|}{$7,1^{\circ} \mathrm{C}$} \\
\hline & & \multicolumn{6}{|c|}{$\begin{array}{l}\text { suma temperatur efektywnych }\left({ }^{\circ} \mathrm{D}\right) \text { potrzebna do wylęgu } 50 \text { i } 100 \% \text { larw } \\
\text { cumulative degree-days }\left({ }^{\circ} \mathrm{D}\right) \text { to } 50 \text { and } 100 \% \text { hatching }\end{array}$} \\
\hline & & $50 \%$ & $100 \%$ & $50 \%$ & $100 \%$ & $50 \%$ & $100 \%$ \\
\hline \multirow{4}{*}{$\begin{array}{c}\text { Od } 1 \\
\text { stycznia } \\
\text { From 1st of } \\
\text { January }\end{array}$} & 1 dzień $^{\text {a) }}-1$ day & $\begin{array}{l}119,13 \\
( \pm 8,36)\end{array}$ & $\begin{array}{c}182,73 \\
( \pm 14,38)\end{array}$ & $\begin{array}{c}98,63 \\
( \pm 11,02)\end{array}$ & $\begin{array}{c}158,03 \\
( \pm 16,99)\end{array}$ & $\begin{array}{c}56,13 \\
( \pm 12,85)\end{array}$ & $\begin{array}{c}105,03 \\
( \pm 19,89)\end{array}$ \\
\hline & $C V_{\text {day }}$ & $12,59 \%$ & $14,50 \%$ & $19,35 \%$ & $18,62 \%$ & $39,65 \%$ & $32,81 \%$ \\
\hline & $3 \mathrm{dni}^{\mathrm{b})}-3$ days & $\begin{array}{c}115,0 \\
( \pm 9,92)\end{array}$ & $\begin{array}{c}178,66 \\
( \pm 15,48)\end{array}$ & $\begin{array}{c}96,46 \\
( \pm 10,07)\end{array}$ & $\begin{array}{c}155,86 \\
( \pm 16,60)\end{array}$ & $\begin{array}{c}55,86 \\
( \pm 12,80)\end{array}$ & $\begin{array}{c}104,76 \\
( \pm 19,83)\end{array}$ \\
\hline & $C V_{\text {day }}$ & $14,43 \%$ & $14,67 \%$ & $18,08 \%$ & $18,45 \%$ & $39,70 \%$ & $32,79 \%$ \\
\hline \multirow{4}{*}{$\begin{array}{l}\text { Od } 1 \text { marca } \\
\text { From 1st of } \\
\text { March }\end{array}$} & 1 dzien $^{a)}-1$ day & $\begin{array}{c}103,30 \\
( \pm 22,05)\end{array}$ & $\begin{array}{c}166,90 \\
( \pm 26,15)\end{array}$ & $\begin{array}{c}87,63 \\
( \pm 20,00)\end{array}$ & $\begin{array}{c}147,0 \\
( \pm 24,88)\end{array}$ & $\begin{array}{c}53,66 \\
( \pm 15,17)\end{array}$ & $\begin{array}{c}102,56 \\
( \pm 21,91)\end{array}$ \\
\hline & $C V_{\text {day }}$ & $36,9 \%$ & $27,14 \%$ & $39,50 \%$ & $29,31 \%$ & $48,98 \%$ & $37,0 \%$ \\
\hline & 3 dni $^{\text {b) }}-3$ days & $\begin{array}{l}101,96 \\
(+21,26)\end{array}$ & $\begin{array}{l}165,56 \\
(+25,03)\end{array}$ & $\begin{array}{c}86,86 \\
(+19,53)\end{array}$ & $\begin{array}{l}146,26 \\
( \pm 24,21)\end{array}$ & $\begin{array}{c}53,13 \\
( \pm 15,48)\end{array}$ & $\begin{array}{l}102,03 \\
( \pm 22,14)\end{array}$ \\
\hline & $C V_{\text {day }}$ & $36,12 \%$ & $26,15 \%$ & $38,90 \%$ & $28,68 \%$ & $50,47 \%$ & $37,58 \%$ \\
\hline
\end{tabular}

a) jeden dzień z temperaturą powyżej zera fizjologicznego - one day with the temperature above the lower developmental threshold

b) trzy kolejne dni z temperaturą powyżej zera fizjologicznego - three days with the temperature above the lower developmental threshold

potrzebna była suma temperatur efektywnych 119,13 stopnio-dni, a do wylęgu 100\% larw suma 182,73 stopnio-dni (tab. 2). Z kolei Richmond i Shetlar (1996) prowadząc badania nad sumą temperatur potrzebną do wylęgu 50 i 100\% larw O. ununguis na świerku kłującym, rosnącym w stanie Ohio w USA, otrzymali wartości odpowiednio o 17,8 i 24,8 stopnio-dni wyższe od uzyskanych przez autorów niniejszej pracy. Badacze ci przyjęli jednak inne wartości zera fizjologicznego i biofixu. Obserwowane różnice mogą również wynikać z odmiennych warunków klimatycznych, w których prowadzono obserwacje. Według Fox i Morrow (1981) oraz Caprio i Tabashnick (1992) różnice w rozwoju roślinożernych stawonogów mogą wynikać z ich adaptacji do warunków lokalnych. O tym jak istotne jest przeprowadzanie tego typu badań dla poszczególnych regionów występowania szkodnika, dowodzą również obserwacje Löyttyniemi (1970). Badacz wykazał, że uznając $5^{\circ} \mathrm{C}$ za wartość progową rozwoju jaj przędziorka sosnowca, suma ciepła potrzebna do wylęgu pierwszych larw roztoczy, w zależności od rejonu Finlandii wahała się od 49 aż do 154 stopnio-dni.

Według Broufas i Koveos (2000) wyznaczanie optymalnego terminu zwalczania przędziorków w oparciu o sumy temperatur efektywnych nie jest metodą skuteczną, jeśli wylęg $\mathrm{z}$ jaj zimujących jest mocno rozciągnięty w czasie. Obserwacje prowadzone w ramach niniejszej pracy wykazały, że o ile w warunkach laboratoryjnych wylęg z jaj zimujących $O$. ununguis, zebranych w styczniu czy lutym trwał od 15,7 do 30,7 dni (tab. 1), to w warunkach naturalnych wylęg larw szkodnika był bardzo wy- równany i trwał od 6 do 10 dni. Jak podaje Miller (1952) fluktuacje temperatury, cechujące warunki naturalne, mogą przyśpieszać rozwój postdiapautyczny jaj przędziorków, co mogłoby tłumaczyć bardziej wyrównany i szybszy niż w laboratorium rozwój jaj przędziorka sosnowca.

\section{Wnioski / Conclusions}

1. Statystyczna analiza danych, pochodzących z badań własnych nad sumą temperatur efektywnych wykazała, że wśród testowanych temperatur, najbardziej prawdopodobną wartością zera fizjologicznego dla rozwoju jaj zimujących przędziorka sosnowca jest $5^{\circ} \mathrm{C}$.

2. Na podstawie przeprowadzonych obserwacji ustalono, że w warunkach Polski centralnej O. ununguis kończy diapauzę zimową na przełomie grudnia i stycznia. Zatem termin ten można przyjąć za biofix date do naliczania sumy ciepła niezbędnej do wylęgu larw przędziorka sosnowca z jaj zimujących.

3. Sumując od pierwszego stycznia średnie temperatury dobowe powyżej wartości zera fizjologicznego $\left(5^{\circ} \mathrm{C}\right)$, do wylęgu $50 \%$ larw $O$. ununguis potrzebne jest 119 stopnio-dni, natomiast do wylęgu 100\% larw około 183 stopnio-dni.

4. Wyrównany wylęg larw O. ununguis z jaj zimujących obserwowany $\mathrm{w}$ trakcie trzech lat doświadczeń polowych, wskazuje na możliwość wykorzystania wyznaczonych sum temperatur efektywnych w celu optymalizacji terminu wiosennego zabiegu przeciwko temu szkodnikowi. 


\section{Literatura / References}

Ahmad T.R., Ali M.A., Hamad B.Sh. 1995. Using degree-days model to determine the optimum spray timing for the codling moth Cydia pomonella (L.) (Lep., Olethreutidae). Journal of Applied Entomology 119 (1-5): 143-144.

Akita Y. 1971. Biological studies of the common conifer spider mite, Oligonychus ununguis Jacobi (Acarina: Tetranychidae). Bulletin of the Government Forest Experiment Station 236, 25 pp.

Bogatko W., Łabanowski G.S., Pala E. 1987. Effect of feeding of the spruce spider mite, Oligonychus ununguis (Jacobi), on the growth and quality of dwarf spruces. Prace Instytutu Sadownictwa i Kwiaciarstwa, Seria B: Rośliny Ozdobne 11: 285-288.

Brammanis L. 1957. Zur Kenntnis des Vorkomments und der Bekämpfung der Nadelholzmilbe, Paratetranychus ununguis (Jac.) (Acari, Trombidiformes). Zeitschrift für Angewandte Entomologie 41: 159-171.

Broufas G.D., Koveos D.S. 2000. Threshold temperature for post-diapause development and degree-days hatiching of winter eggs of the European red mite (Acari:Tetranychidae) in Norten Greece. Environmental Entomology 29 (4): 710-713.

Caprio M.A., Tabashnick B.E. 1992. Gene flow accelerates local adaptation among finite populations: simulating the evolution of insecticide resistance. Journal of Economic Entomology 85: 611-620.

Czajkowska B., Kiełkiewicz M., Puchalska E. 2003. Population parameters as an indicator of susceptibility of ornamental coniferous plants to spruce spider mite. Journal of Plant Protection Research 43 (2): 155-162.

Fox L.R., Morrow P.A. 1981. Specialization: species property or local phenomenon? Science, Washington DC 211: 887-893.

Herms D.A. 2004. Using degree-days and plant phenology to predict pest activity p. 49-59. In: "IPM (Integrated Pest Management) of Midwest Landscapes" (V. Krischik, J. Davidson, eds.). Minnesota Agricultural Experiment Station Publication 58-07645, 316 pp.

Jakubowska M., Walczak F. 2010. Praktyczne wykorzystanie wyznaczonych sum temperatur efektywnych do wspomagania określenia terminu chemicznej ochrony buraka cukrowego przed rolnicami (Noctuidae: Noctuinae). [Practical use of determinet sum of effective temperatures in controling cutworms in sugar beet]. Progress in Plant Protection/Postępy w Ochronie Roślin 50 (1): $23-28$.

Kiełkiewicz M., Puchalska E., Czajkowska B. 2005. Changes in biochemical composition of needles of ornamental dwarf spruce (Picea glauca 'Conica') induced by spruce spider mite (Oligonychus ununguis Jacobi, Acari: Tetranychidae) feeding. Acta Physiologiae Plantarum 27 (4): 463-471.

Löyttyniemi K. 1970. Zur Biologie der Nadelholzspinnmilbe (Oligonychus ununguis (Jacobi), Acarida, Tetranychidae) in Finnland. Acta Entomologica Fennica 27: 1-64.

Łabanowski G.S. 1979. Ekologiczne i ekonomiczne podstawy zwalczania owocówki jabłkóweczki (Laspeyresia pomonella L.). Praca doktorska. Instytut Sadownictwa, Skierniewice, $121 \mathrm{ss}$

Miller R.W. 1952. The hatching of overwintering eggs of the European red mite. Tasmanian Journal of Agriculture 23: 102-116.

Murray M.S. 2008. Using degree days to time treatments for insect pests. Utah Pest Fact Sheet. IPM-05-08. https://climate.usurf.usu.edu [Accessed: 23.01.2016].

Puchalska E. 2006. The influence of Oligonychus ununguis Jacobi (Acari: Tetranychidae) on photosynthetic activity and needle damage of Picea glauca 'Conica'. Biological Letters 43 (2): 353-360.

Puchalska E.K. 2014. Occurrence of spider mites (Prostigmata: Tetranychidae) and phytoseiid mites (Mesostigmata: Phytoseiidae) as their potential enemies, on Norway spruce (Picea abies (L.) and its cultivars grown in ornamental plant nurseries in Poland. Acta Scientiarum Polonorum, Hortorum Cultus 13 (6): 161-172.

Richmond D.S., Shetlar D.J. 1996. Eclosion time and spatial distribution of overwintering spruce spider mite (Acari: Tetranychidae) eggs on Colorado spruce. Journal of Economic Entomology 89 (2): 447-452.

Trottier R., Herne D.H.C. 1979. Temperature relationship to forecast hatching of overwintered eggs of the european red mite, Panonychus ulmi (Acarina: Tetranychidae). Proceedings of the Entomological Society of Ontario 110: 53-60.

Veerman A. 1985. Diapause. p. 279-316. In: "Spider Mites their Biology, Natural Enemies and Control. World Crop Pest Vol. 1A" (W. Helle, M.W. Sabelis, eds.). Elsevier, Amsterdam - Oxford - New York - Tokyo, 405 pp.

Yang S., Logan J., Coffey D.L. 1995. Mathematical formulae for calculating the base temperature for growing degree days. Agricultural and Forest Meteorology 74: 61-74. 